\title{
ORANG TIDUNG DI PULAU SEBATIK; IDENTITAS ETNIK, BUDAYA DAN KEHIDUPAN KEAGAMAAN
}

\author{
TIDUNG PEOPLE IN SEBATIK ISLAND; \\ ETHNIC IDENTITY, CULTURE, AND RELIGIOUS LIFE
}

\author{
Muhammad Yamin Sani \\ Universitas Hasanuddin \\ JL. Perintis Kemerdekaan Km. 10 Tamalanrea Makassar \\ E-mail : yaminsani.muh@gmail.com \\ Rismawati Isbon \\ Universitas Tadulako, Palu \\ JL. Soekarno Hatta, Km.9 Tondo, Mantikulore Palu \\ E-mail : rismawatiisbonp@gmail.com
}

Naskah diterima tanggal 5 April 2018. Naskah direvisi tanggal 23 April 2018. Naskah disetujui tanggal 18 Mei 2018

\begin{abstract}
Artikel ini merupakan bagian dari hasil penelitian berjudul Orang Tidung di Tapal Batas Membangun Negeri Merawat Harmoni : Kajian Hubungan Antarsuku bangsa di Kabupaten Nunukan Kalimantan Utara. Penelitian etnografi kritis ini mengkaji konstruksi identitas etnik dan aspek budaya orang Tidung di Kabupaten Nunukan. Data dianalisis secara interaktif, meliputi reduksi data, displai data dan verifikasi. Hasil penelitian menunjukkan, identitas etnik Tidung, terbangun dari beberapa versi dari hasil interpretasi kelompok-kelompok etnis Tidung sendiri yang berasal dari beberapa daerah di Kalimantan Utara, bahkan orang Tidung yang berasal dari Malaysia Timur. Terdapat dua pendapat dari versi identitas orang Tidung. Pertama, orang Tidung adalah bagian dari etnis Dayak dan kedua orang Tidung sebagaimana yang ada dalam mitologi adalah kelompok etnis tersendiri. Dalam perkembangannya, orang Tidung di beberapa daerah, seperti orang Tidung di Tarakan tergolong maju, sementara lainnya, seperti orang Tidung di Kabupaten Nunukan tergolong masih hidup secara sederhana. Kesederhanaan orang Tidung di Kabupaten Nunukan tercermin dari orientasi nilai budaya yang mereka miliki untuk hidup secara bersahaja. Dalam kehidupan keagamaan, generasi tua orang Tidung tergolong Islam pluralistik, sementara generasi mudanya berupaya membebaskan diri dari unsur-unsur pluralisme dalam agama Islam yang mereka anut. Dalam era reformasi ini, terlihat mulai terbangunnya kesadaran akan penguatan politik identitas yang ditandai dengan munculnya "Pan Dayak" yang mencerminkan arena persaudaraan antara orang Dayak dengan orang Tidung dalam organisasi PUSAKA (Persatuan Suku Asli Kalimantan). Semangat kebangkitan politik identitas perlu dicermati, karena Kabupaten Nunukan termasuk wilayah yang pluralistik.
\end{abstract}

Kata Kunci : Orang Tidung, identitas etnik, budaya, kehidupan keagamaan

\begin{abstract}
Abstrak
This article was a part of research result titled "Tidung People in State Line Build Nation Caring Harmony: A Study on Inter-Tribes Relations in Nunukan District of North Kalimantan.This research as critical ethnographic research examines the construction of ethnic identity and cultural aspect of Tidung people in Nunukan district. Data were analyzed interactively includes data reduction, data display, and verification. The results of the research indicate that ethnic identity of Tidung was built from several versions of interpretation result of Tidung ethnic groups it self originating from several areas in North Kalimantan, even Tidung people from East Malaysia. There is two opinion of Tidung people identity version. The first, Tidung people are part of Dayak ethnic and the second, Tidung people as in mythology is a distinct ethnic group. In its development, Tidung people in some areas such as in Tarakan is classified develop, while another area such as in Nunukan is classified as people with living simply. The simplicity of Tidung people in Nunukan district is reflected in their cultural orientation for a homely life. In religious life, Tidung older
\end{abstract}


generation is classified as pluralistic Islam while the young generation tries to release from the pluralism in their religion. In this reformation era, appears the awareness of identity politic strengthening as indicated by the emergence of "Pan Dayak" that reflects brotherhood arena between Dayak and Tidung people in PUSAKA (Persatuan Suku Asli Kalimantan) organization. The spirit of identity politic renaissance should be observed because Nunukan district is a pluralistic area.

Keywords: Tidung people, ethnic identity, culture, religious life

\section{PENDAHULUAN}

A da hal menarik menulis orang Tidung di Pulau Sebatik, sebuah pulau yang menjadi Tapal Batas Indonesia - Malaysia di Kabupaten Nunukan. Pertama orang Tidung di pulau ini hanya bermukim di tiga buah desa Kecamatan Sebatik Barat. Padahal di Pulau Sebatik terdapat 4 kecamatan, ini berarti orang Tidung, tergolong minoritas dari orang Bugis yang menjadi penduduk mayoritas di pulau tersebut. Namun demikian, orang Tidung adalah penduduk asli Pulau Sebatik yang telah menjadi penghuni tetap sejak abad 17. Dengan tangan terbuka orang Tidung menerima para migran, terutama migran Bugis yang kemudian menjadi penguasa Pulau Sebatik.

Konsekuensinya, Pulau Sebatik yang membawahi empat kecamatan, menjadi sebuah pulau dengan penduduk multi etnis : Bugis, Jawa, Flores, dan beberapa etnik lainnya. Namun demikian, para migran tersebut telah menjadikan pulau ini lebih maju. Sebaliknya, orang Tidung tidak banyak berubah. Orang Tidung, terlihat menjadi kelompok etnis yang memiliki batas-batas yang jelas (well-defined boundaries) yang membedakan antara etnik Tidung dengan etnik lainnya di pulau tersebut.

Naroll (Barth, 1988:11) yang mengidentifikasi kelompok etnik sebagai satu kesatuan pendudukan dengan ciri-ciri : (1) secara tertutup berkembang biak dalam kelompoknya; (2) memiliki nilainilai dasar yang terwujud dan tercermin dalam kebudayaan; (3) mewujudkan arena komunikasi dan interaksi sosial, dan (4) mempunyai anggota yang mengenali dirinya serta dikenali oleh orang lain sebagai bagian dari satu kategori yang dapat dibedakan dengan kategori lainnya.

Pandangan di atas sebenarnya terlalu ekstrim. Kelompok etnis dengan ciri well define boundaries, ada ketika suatu kelompok etnis masih dalam kelompok-kelompok kecil yang hidup pada lingkungan yang relatif tertutup dengan sentimen kemasyarakatan yang kuat. Sudah barang tentu, kelompok masyarakat seperti ini, sudah sulit dijumpai karena berbagai faktor seperti semakin berkembangbiaknya populasi, maupun jaringan- jaringan sosial dengan etnis lain. Bahkan hubungan kawin-mawin yang memungkinkan terjadinya fenomena akulturasi, maupun asimilasi.

Orang Tidung sebenarnya, bukanlah etnik yang masih tertutup, karena sudah terjadi hubunganhubungan sosial dengan etnik lain. Namun demikian, bagi masyarakat lain di pulau Sebatik, memiliki streotip sendiri sebagai masyarakat yang hidup sederhana dengan orientasi nilai budaya yang cenderung menghargai masa lalu dengan sedikit masa kini. Karena itu, dalam bekerja mereka tidak memburu status sosial, tetapi secukupnya saja sehingga terkesan terkebelakang atau tertinggal dibanding kelompok etnis pendatang atau para migran, terutama dari kalangan migran Bugis.

Gejalainisebenarnyasangatmengkhawatirkan jika tidak dikelola secara benar. Masyarakat lokal yang merasa termarginalkan, akan membangun kesadaran internal untuk melakukan resistensi. Agaknya, di sini letak pentingnya tulisan ini agar dapat memahami identitas etnik Tidung, kebudayaan dan kehidupan keagamaannya, agar dapat lebih mudah mengintegrasikan kelompok etnis ini dalam pembangunan.

\section{Konstruksi Identitas Orang Tidung}

Menurut Amir Hamzah (1999 : 21) asal usul orang Tidung saat ini setidaknya terbagi ke dalam 3 versi, yakni 1) versi masyarakat Tidung sendiri, 2) versi pemerintahan Hindia Belanda dan 3) versi pemerintah Republik Indonesia Cq. Pemerintah Kabupaten Bulungan. Pengertian ketiga versi tersebut berbeda-beda.

Pertama, versi menurut masyarakat Tidung yang meyakini, bahwa nenek moyang mereka berasal dari daratan Asia yang bermigrasi sekitar abad ke V - I SM. Saat itu, terjadi eksodus manusia dari daratan Asia menuju pulau-pulau di sebelah Timur dan Selatan. Diduga mereka mendarat di pantai Timur Pulau Kalimantan bagian Utara yaitu sekitar daerah Labuk dan Kinabatangan. Kemudian, mereka menyebar dengan berbagai alasan ke daerah-daerah pesisir pantai dan di tepitepi sungai besar serta di pulau-pulau di sebelah Timurnya seperti pantai Timur Sabah berbatasan dengan daerah Kudat di Utara hingga Tanjung 
Mangkalihat di Selatan. Ekspansi mereka ini kadang kala mendapat perlawanan dari penduduk yang lebih awal menempati daerah itu dan mendorong penduduk itu untuk masuk lebih ke dalam hutan dan hulu sungai. Mereka ini kita kenal sekarang sebagai suku bangsa Dayak Kayan.

Saat ini, daerah mereka dikenal beberapa wilayah seperti Tarakan, Bunyu (Bulungan), Nunukan, Sebatik (Kab. Nunukan), Malinau, Bulungan, Sembakung, Salimbatu Sumbel, Sesayap (Kab. Tana Tidung), Pembeliangan, Tawau Tinagad - Kelumpang - Selungun - Timbun Mata Sandakan - Labuk (Malaysia). Daerah-daerah inilah yang kemudian secara totalitas disebut Tana Tidung.

Kedua, versi Hindia-Belanda yang menyatakan bahwa asal usul orang Tidung berasal dari Dayak Kayan. Versi ini ditengarai dilatarbelakangi kepentingan politik tertentu, dimana yang dimaksud Tidung asli adalah daerah yang hanya melingkupi Sesayap dan Malinau dengan mengabaikan konsentrasi pemukiman penduduk Tidung lainnya. Nomenklatur Belanda ini menyebabkan masyarakat Malinau dan Sesayap mengklaim dirinya sebagai Tidung Asli dan wilayahnya adalah Tana Tidung, sementara itu masyarakat Tidung di tempat lain pun mengklaim dirinya sebagai Tidung Asli. Demikian seterusnya sehingga rasa persatuan di antara mereka semakin longgar yang diperparah lagi dengan saling hina dalam pemakaian bahasa Tidung.

Ketiga, versi Pemerintah Indonesia cq. Bagian Tata Pemerintahan Kantor Bupati Bulungan. Dalam buku monografi Kabupaten Bulungan menyebutkan bahwa suku bangsa Tidung adalah Dayak Pantai yang berasal dari daerah pegunungan di Menjelutung. Orang Tidung di Pulau Sebatik mendiami wilayah pantai sebagai bagian dari Nunukan, yang dibesarkan di lingkungan keluarga yang rendah hati dan sederhana. Mereka yang menyebut dirinya sebagai orang kampung (ulun pagun)yang bermukim di sekitar pinggiran sungai dan wilayah pesisir. Bahkan permukimannya pernah berpindah-pindah dari satu pinggiran sungai ke pinggiran sungai lainnya.

Kini orang-orang Tidung tersebar di sepanjang wilayah timur laut pulau Kalimantan dan pulau-pulau kecil sekitarnya. Di antaranya adalah di Kecamatan Nunukan dan di Kecamatan Sebatik Barat. Semenjak negara terbentuk, mereka telah menerapkan pola bermukim secara menetap. Pulau Sebatik yang ditempati mereka merupakan salah satu arena berlangsungnya insiden konfrontasi.
Peristiwa konfrontasi yang melibatkan Orang Tidung dalam mempertahankan kedaulatan negara membuat mereka memilih menetap di sebuah tempat yang menjadi saksi sejarah atas perjuangannya, walaupun sanak saudara dan pertalian kekerabatan mereka dipisahkan oleh patok perbatasan kedua negara di pulau ini. Ikatan persaudaraan antar orang Tidung sangat kuat dan pola permukimannya yang belimpun (berdekatan) dengan siapa yang dianggap sebagai pensulot sehingga membentuk komunitas perkampungan.

Orang Tidung di Pulau Sebatik yang terbentuk hari ini dimotori oleh proses menafsirkan kembali peristiwa silam melalui jaring-jaring ingatan dengan proses mental dan pemaknaan yang kontekstual sehingga membentuk sebuah rangkaian perjalanan historis dari pengalaman yang muncul ke permukaan dan terus direproduksi oleh mereka. Orang Tidung di Sebatik teridentifikasi berasal dari berbagai kampung yang terdapat di dataran induk Borneo. Kelompok orang Tidung secara menyeluruh yang tersebar di wilayah Semenanjung Timur Laut Dataran Borneo terdiri dari tujuh kelompok yang merupakan kelompok sub bagian dari orang Tidung Sembakung, Sebuku, Tanah Merah, Tarakan, dan Bulungan.

Menurut Idris (2017 : 60) terdapat 4 versi mengenai asal-usul orang Tidung yaitu : Pertama, mitologi bahwa asal muasal orang Tidung berasal dari sebuah telur yang berada di atas sebuah pohon bambu. Awalnya dikisahkan bahwa ada salah satu suku Dayak yang menjadi pendahulu orang Tidung. Dalam versi ini, asal usul orang Tidung bukan langsung dari manusia, walaupun cerita sudah kurang diketahui oleh orang Tidung sendiri. Jadi dulu dua kerajaan Dayak, memgawinkan anak mereka masing-masing. Anak dari raja tersebut setelah menikah menjadi pasangan suami-istri. Suatu ketika si istri itu hamil, dan mengidam ingin memakan daging buruan. Kemudian suami mengutus beberapa prajurit untuk berburu di hutan agar memenuhi permintaan istrinya. Para prajurit beserta anjingnya bergegas menuju hutan untuk berburu dan menelusuri perbukitan, semaksemak, dan lembah-lembah. Namun, hari itu tak ada satupun binatang yang mereka temukan. Cicak, kadal dan serangga pun tak ada, apalagi seperti burung, babi dan kijang. Hanya saja pada saat perjalanan pulang, anjing yang menyertai prajurit itu, terus menggonggongi rumpunan pohon bambu. Prajurit itu heran mengapa anjingnya menggonggongi pohon bambu tersebut. Lalu oleh 
prajurit itu kemudian mulai memeriksa pohon. Ternyata di balik pohon bambu itu terdapat sebuah telur yang sangat besar. Lalu telur itu diambil prajurit untuk dibawah pulang untuk diperlihatkan kepada anak raja, suami dari istrinya yang lagi mengidam ingin memakan daging buruan.

Sesampainya di rumah, diperlihatkan oleh raja dan raja menginginkan agar telur itu ditunggu sampai masa penetasannya, agar dapat diketahui telur ini dari jenis binatang apa. Setelah ditunggu seminggu akhirnya telur itu menetas dan yang ada dalam telur itu ternyata adalah manusia. Anak manusia yang lahir dari telur itu pun oleh sang raja diberi nama sebagai Tidong, kamu ini orang Tidong. Karena asal didapatkannya telur ini dari atas bukit gunung-gunung di tengah hutan. Kemudian anak itu pun tumbuh layaknya manusia yang lain, serta menikah beranak-pinak hingga membentuk perkampungan sendiri dan tinggal di daerah perbukitan. Seluruh keturunan Aki Tidung yang diyakini lahir dari telur yang ditemukan di bukit tengah hutan ini disebut sebagai orang Tidung yang saat ini tersebar di wilayah pulau Kalimantan Bagian Timur Laut.

Cerita ini menggambarkan bahwa orang Tidung yang ada saat ini berasal dari telur yang merupakan suatu fenomena yang unik, karena dalam mitos tersebut orang Tidung pada awalnya bukanlah ada dan terbentuk langsung menjadi manusia, melainkan dari telur yang sifatnya sangat gaib. Namun, sebelumnya dikisahkan bahwa yang menemukan telur yang menjadi cikal-bakal orang Tidung adalah orang Dayak.

Mitologi versi pertama ini Iebih banyak dipertahankan oleh orang Tidung dari kelompok sesayap yang mendiami wilayah Tarakan, Tanah Merah, Pulau Mandul. Sedangkan untuk Orang Tidung yang tinggal di daerah pedalaman seperti di Sembakung dan Sebuku menganggap bahwa kisah mengenai mitologi asal-usul Tidung yang berasal dari telur merupakan kisah dari asal-usul suku Bulungan. Dan faktanya pada saat ini di antara kalangan Tidung dan Bulungan terdapat pemisahan tegas antar suku mereka. Orang Tidung tak mau mengakui bahwa Bulungan merupakan bagian dari mereka dan begitu pula sebaliknya.

Kedua,mitologi mengenai asal-muasal orang Tidung versi Tidung Sebuku. Kelompok subetnik Tidung Sebuku diyakini oleh masyarakat berasal dari sungai Sumbal yang berada di sekitar wilayah Kecamatan Sebuku Kabupaten Nunukan. Orangorang Tidung Sebuku yang berasal dari sungai
Sumbal inilah kemudian menyebar ke berbagai tempat di Semenanjung Bagian Timur Laut Pulau Kalimantan dan pulau-pulau sekitarnya.

Menurut versi ini orang Tidung dahulu kala tinggal di sepanjang sungai-sungai di pertengahan Borneo Timur hingga ke utara di Batu Tinagat dekat Tawau. Bukti jelas eksistensi sukubangsa Tidung adalah yang terawal di kawasan daerah Tawau ialah nama tempat yang menggunakan panggilan dalam bahasa Tidung seperti nama Tinagat yang berarti 'tebang' dan Membalua yang berarti 'hantu'. Batu Tinagat atau Batu Payung berasal dari cerita masyarakat Tidung Tawau (Batubara, 2014 : 130).

Kaitan antara Tidung Tawau dan orang Tidung asal Sebuku merupakan cerita lisan yang diinformasikan secara historis ini telah mengalami perubahan. Berdasarkan Tidung Tawau hanya mengisahkan peristiwa yang berkaitan dengan penamaan Tawau dan Batu Tinagat, sedangkan Tidung yang berasal dari sungai Sumbal mengisahkan asal-usul orang Tidung dari hutan di Sebuku sampai ke Tawau. Adanya unsur kesamaan kisah antara Tidung di Tawau dengan di Sebuku memperlihatkan bahwa sub-sub kelompok Tidung yang tersebar di daerah yang berdekatan ini merupakan satu rumpun, meskipun terdapat sedikit perbedaan terhadap mitos yang dibangun dan diinformasikan secara lisan dari satu generasi ke generasi selanjutnya.

Ketiga, mitologi mengenai asal-muasal orang Tidung versi Tidung Sembakung. Mitos ini dikembangkan oleh orang-orang Tidung yang berasal dari Sembakung yang ada di Pulau Sebatik. Mitologi ini didasarkan pada mitos mengenai Aki Suruga, yang dirumorkan mempunyai tinggi badan 5 hasta. Informasi tentang asal-usul orang Tidung dari Sembakung yang dahulu menjadi bagian dari suku asli Kalimantan yang masih mengikuti ajaran nenek moyang mereka. Dikisahkan bahwa dahulu dalam keluarga Tidung ada dua bersaudara kakak beradik. Kakaknya bertemu dengan seorang wali di hutan dan mengajarkan mengenai ajaran Islam. Sesampai di rumah sang kakak ingin mengajarkan ke adiknya. Namun, adiknya masih ingin menjalankan ajaran dari leluhurnya. Sebagai akibat masing-masing mempertahankan pendapatnya, maka kakak dan adik membagi wilayah kekuasaannya dan memilih untuk berpisah karena perbedaan kepercayaan. Berpatokan pada aliran sungai, wilayah kekuasaan kakak sampai pada pertemuan air asin dengan air tawar di sungai, sedangkan wilayah adik pada aliran sungai yang tak bercampur air asin. Artinya wilayah kakak adalah hilir sungai sedangkan wilayah adik 
adalah hulu sungai. Perjanjian tersebut merupakan sebuah perjanjian untuk membagi kekuasaan antara orang Tidung dengan orang Dayak. Untuk itulah orang-orang Tidung saat ini lebih banyak tersebar pada wilayah pinggiran sungai bagian hilir dengan wilayah pesisir dan pulau-pulau sekitar Dataran Borneo.

Ada pendapat, bahwa orang-orang Tidung yang ada dan bermukim di Sebatik berasal dari berbagai sub suku Tidung, yang berasal dari kelompok Tidung Sebuku, kelompok Tidung Sembakung, dan Kelompok Tidung Sesayap. Dari segi dialek bahasa yang digunakan ketiga sub suku ini memiliki dialek yang berbeda. Tidung Sebuku dan Sembakung yang berasal dari pedalaman Sungai Sumbal dan Sungai Sembakung dikategorikan sebagai kelompok Tidung pedalaman. Sedangkan Tidung Tarakan adalah kelompok Tidung yang telah lebih maju karena tinggal di wilayah pesisir yang membuat mereka telah mengalami kontak dengan suku lain akibat adanya perdagangan laut. Walaupun orang Tidung berasal dari berbagai sub kelompok etnis dari berbagai daerah yang terpencar, mereka dipersatukan dengan nilai belimpun, dengan semboyan belimpun taka tagas, usuwai taka tapu yang berarti menyatu kita layaknya kayu ulin dan bercerai-berai kita layaknya tebu. Semboyan ini bermakna bahwa orang Tidung haruslah bersatu, jangan berbeda pendapat dan terpecah-belah karena hal itu dapat membawa kehancuran dan membuat orang Tidung lemah dan gampang terprovokasi. Untuk itulah nilai dan semboyaan ini dibangun dalam rangka penguatan identitas ke-Tidung-an untuk mempersatukan dan mengikat subsuku Tidung yang berasal dari daerah yang berbeda dengan perbedaan dialek bahasa. Dengan semboyan ini kelompok sub Tidung yang berasal dari Sebuku, Sembakung, dan Tarakan menyatu dengan mengangkat identitas keTidung-an. Okushima (2003: 21) mengkategorikan sub suku Tidung menjadi empat kategori, yakni kelompok Sesayap, kelompok Sebuku, Sembakung, dan kelompok Bulungan. Namun untuk orang Tidung yang di Sebatik tak menganggap lagi bahwa kelompok Bulungan sebagai sub kelompok Orang Tidung.

Keempat, mitologi mengenai asal-usul orang Tidung dari versi Malaysia. Dalam versi ini menyebutkan bahwa orang Tidung adalah hasil perpaduan antara dua etnis yakni etnis Dayak Murut dan etnis Suluk. Etnis Suluk yang datang ke Sabah untuk memperkuat ekspansinya di dataran Borneo mengawini penduduk setempat yakni Dayak Murut, yang dikisahkan dalam mitos menikahi putri dari kayangan, sebenarnya adalah bahasa yang sangat hiperbolik. Orang kayangan yang dimaksudkan adalah orang gunung yang tinggal di daerah atas. Sedangkan orang Suluk adalah kelompok yang mendiami wilayah pesisir dan pulau-pulau. Perkawinan antar etnis itu menyebabkan proses islamisasi yang dilakukan oleh Kerajaan Suluk ke kelompok Dayak Murut, yang akhirnya Dayak Murut yang telah Islam telah mengubah identitas mereka menjadi orang Tidung. Tidung merupakan istilah yang merujuk pada tempat yang berada di dataran tinggi, jadi walaupun mereka pada umumnya mendiami wilayah pesisir, namun asalusul mereka berasal dari gunung. Mitologi ini didasarkan pada ekspansi Kesultanan Suluk atas Wilayah Sabah. Dari mitos inilah asal-muasal Tidung yang berasal dari daerah Kinabatangan, terus menyebar ke daerah Tawau, Apas, Klabakan, dan juga menyebar ke beberapa daerah di Indonesia seperti di Sebuku dan Sembakung.

Perbedaan yang mencolok mengenai asalusul Tidung versi Malaysia dan versi Indonesia yang dipaparkan di atas merupakan sebuah wacana untuk mengklaim bahwa Tidung merupakan etnis yang berasal dari negara masing-masing dan membangun identitas orang Tidung. Namun demikian, baik dari Tidung Malaysia maupun Tidung di Indonesia, masih memiliki ikatan tali kekerabatan, karena penyebaran mereka di wilayah Sabah dengan Kalimantan Utara jauh lebih dulu hadir dibandingkan dengan terbentuknya negara di wilayah ini.

Mitos yang dikonstruksi oleh kelompok sub etnis Tidung, baik yang berasal dari kelompok Sebuku, Sembakung, dan Sesayap merupakan sebuah strategi kebudayaan dalam rangka untuk membangun identitas dan mendiferensiasi dengan kelompok lain. Seperti yang dikatakan oleh Van Peursen (1988 : 61) bahwa mitos adalah sebuah cerita yang menjadi pedoman dan arah tertentu kepada sekelompok orang yang melambangkan identitas dirinya. Terutama pada mitos mengenai asal-usul. Karena pada sebuah mitos itu, manusia dapat turut serta mengambil bagian dalam kejadiankejadian sekitarnya, dapat menanggapi daya-daya kekuatan alam.

Dalam hal ini manusia menemukan identitas dirinya. Manusia dikelilingi oleh alam semesta sehingga manusia mudah dimasuki oleh daya dan kekuatan alam. Manusia masih terbuka yang dengan demikian berpartisipasi dengan daya-daya kekuatan alam yang menyadarkan bahwa terdapat daya- 
daya kekuatan gaib yang bersifat mistis. Namun manusia masih belum mampu memandang obyek atau realita dengan inderanya sehingga manusia dan alam bercampur menjadi satu kemudian melahirkan identitas dari hasil perpaduan antara manusia dan alam sekitarnya yang dibentuk melalui mtos asal-usul.

Mengacu pada ketiga mitos inilah dapat diidentifikasi mengenai adanya subkelompok etnik Tidung yang bermigrasi ke Pulau Sebatik. Penelusuran mengenai jejak-jejak perjalanan orangorang Tidungyangbermigrasi ke Pulau Sebatik dapat dilihat dengan adanya peninggalanpeninggalan arkeologis dan dapat pulau ditelusuri dengan jejak ingatan para tetua Tidung yang masih hidup. Terjadi tiga gelombang migrasi ke Sebatik :

Pertama, Periode ini diyakini terjadi pada tahun 1700. Berdasarkan bukti sejarah, terdapat makam tua di Pulau Sebatik bercorak Islam Melayu yang tersebar di beberapa desa. Diidentifikasi bahwa kuburan tua ini merupakan kuburan orang Tidung di masa lalu. Selain itu diperkirakan bahwa pada abad ke 18 merupakan gelombang pertama migrasi orang Tidung di Pulau Sebatik.

Bukti arkeologis berupa kuburan tua yang terdapat di Desa Liang Bunyu' khususnya yang terdapat di kampung Sekapuk Desa Liang Bunyu'. Namun, ada pula makam tua yang terdapat di Kampung Lapeo di Desa Setabu. Kuburan tersebut diyakini sebagai kuburan orang Tidung, karena menurut penuturan informan, kuburan tersebut memiliki ciri-ciri dengan nisan yang bertuliskan Arab Melayu pada namanya, tetapi penulisan tahunnya masih bertuliskan huruf Latin. Kemudian nisannya masih terbuat dari kayu ulin, namun bentuk dan ukirannya telah mencirikan bahwa makam ini merupakan makam orang yang telah beragama Islam. Pada makam tersebut tertulis tanggal meninggalnya hanya tertera tahunnya yaitu pada tahun 1832. Meskipun kondisi nisan telah mulai lapuk dimakan waktu, tetapi nisan pada makam terbuat dari kayu ulin mampu bertahan pada waktu yang cukup lama. Kuburan tersebut merupakan sisa-sisa dari perkampungan yang dulunya didirikan di Kampung Sekapuk. Pada saat ini, perkampungan-perkampungan orang Tidung di daerah Sekapuk, sudah tidak ada lagi.

Berdasarkan pada gelombang pertama orang Tidung yang masih hidup dengan pola bermukim secara berpindah pada abad ke-18. Gelombang pertama ini diketahui merupakan migrasi orang Tidung yang berasal dari Sebuku. Hal ini diperkuat dengan adanya kuburan tua yang terletak di beberapa kampung seperti di Kampung Sekapuk di Desa Liang Bunyu' dan Kampung Lapeo, diduga merupakan kuburan dari orang Tidung, bukti arkeologi berapa makam tua yang bernisan tahun 1836 terdapat di pinggir pantai yang terletak pada sekitaran pohon bambu diyakini merupakan kuburan orang Tidung.

Gelombang kedua terjadi pada saat Kerajaan Tidung di Tarakan yang bergelar Kerajaan Tengara Raja Tidung Tarakan Datuk Adil memerintahkan untuk membuka perkampungan di Pulau Sebatik. Dalam Kerajaan Tidung Tarakan terdapat lima pulau yang menjadi wilayah kekuasaan Kerajaan Tidung, seperti Pulau Tarakan, Pulau Bunyu', Pulau Mandul, Pulau Nunukan, dan Pulau Sebatik yang berada di sekitar dataran Borneo. Dengan perintah dari raja Tidung Tarakan Datuk Adil (1896-1916) dibukalah kampung di Sebatik pada akhir tahun 1813. Dibangunnya Kampung Tidung di Bebatu yang saat ini adalah Desa Setabu, merupakan desa pertama dan tertua di Pulau Sebatik berdasarkan versi pemerintah. Desa atau perkampungan yang dibuka oleh raja yang menjadi persyaratan pembukaan kampungnya adalah harus ada yang melakukan fardhu kifayah dan dukun beranak.

Pada saat pembukaan kampung oleh utusan raja telah ada sekelompok orang Tidung yang telah bermukim sebelumnya dari kalangan Tidung Sebuku di daerah pedalaman. Kemudian, orangorang dari Tidung yang dari Tarakan dulunya hanya sebatas menjadikan Pulau Sebatik sebagai pulau tempat persinggahan semata. Pada masa ini banyak para pelaut yang datang ke Pulau Sebatik untuk mengambil kayu dan mencari rotan, damar dan bahan-bahan lainnya. Hanya saja belum ada yang menetap. Seperti kelompok Suku Bajo, Suku Moro, suku Suluk. Semenjak saat itu perdagangan laut di Tarakan-Nunukan-Sebatik-Tawau dikuasai oleh orang Tidung. Pada tahun 1916, Kerajaan Tidung diserang oleh Kesultanan Bulungan akibat adu domba Belanda sehingga pada akhirnya Kerajaan Tidung Tarakan runtuh dan Raja Datuk Adil diasingkan ke tempat lain, sehingga Kesultanan Bulungan menguasai wilayah Tarakan.

Periode ketiga pada tahun 1911, terjadi setelah Kerajaan Bulungan melancarkan serangan ke daerah yang berdekatan dengan wilayahnya, termasuk pada wilayah Sembakung. Hal ini menyebabkan orang-orang Tidung di Sembakung yang berhasil selamat dari penyerangan melarikan diri ke berbagai daerah, ada yang ke Tarakan, 
Nunukan, Sebatik, Tawau, Kinabatangan, Labuk, Kutai, dan Bahkan sampai ke Pulau Sulu.

Orang Tidung yang berasal dari Sembakung di Pulau Sebatik membuka perkampungan di wilayah Desa Liang Bunyu'. Orang Tidung dari kelompok Sembakung yang datang ke Pulau Sebatik awalnya hanya sebatas mengambil kayu, dan sarang burung wallet yang menjadi komoditi perdagangan laut. Orang-orang Tidung yang datang ke Sebatik hanya mendirikan pondok-pondok kecil yang berada di dekat bibir pantai sebagai penanda tempat persinggahan mereka. Perkampungan yang mereka bangun bernama Beliang Bunyu', yang berarti bahwa "tidak tenang atau merasa was-was kalau tidak kembali". Hal ini dikarenakan orang Tidung yang ada di Sebatik masih memikirkan sanak keluarga yang berpencar ke beberapa daerah, dan kampung asalnya. Namun, lama-kelamaan nama itu berubah menjadi Liang Bunyu' yang berarti lubang buah bunyu'. Nama ini diberikan karena di dekat perkampungan terdapat buah bunyu' dan terdapat pula lubang yang berada di dekatnya.

Tidung merupakan istilah kolektif untuk sekelompok orang kampung yang mendiami wilayah pesisir dan hilir sungai pada wilayah Dataran Borneo Bagian Timur Laut dan pulau-pulau kecil sekitarnya. Penamaannya kemudian dikaitkan dengan nama sungai yang terletak di sekitar pemukiman mereka. Seperti pada Sungai Sumbal di Sebuku, Sungai Sembakung, dan Sungai Sesayap di wilayah Kab. Tanah Tidung. Kemudian penyebaran Suku Tidung pun umumnya terkonsentrasi pada wilayah hilir sungai dan pesisir serta pulau-pulau sekitarnya.

\section{Orientasi Nilai Budaya}

Orientasi nilai budaya merupakan sebuah prinsip ideal yang diyakini akan membawa kebahagiaan. Orientasi nilai budaya juga disebut prinsip hidup, dalam pengertian prinsip yang dijadikan pedoman hidup oleh manusia pemiliknya. Gilirannya, orientasi nilai budaya menjadi pengarah langkah manusia ke depan. Demikian seterusnya sepanjang hidup manusia pemiliknya, baru berhenti pada akhir kesadarannya. Seperti halnya orang Tidung yang memiliki Falsafah Hidup berupa sistem nilai dan norma yang menjadi pedoman hidup orang Tidung dalam menjalani kehidupannya. Ada beberapa falsafah hidup orang Tidung yang masih dijalankan maupun yang sudah ditinggalkan, akibat adanya persentuhan dengan ajaran Islam (Sani, 2017 : 67; Idris, $2017: 170$ ).

Pertama adalah mengayau. Mengayau adalah sebuah nilai yang melatarbelakangi ritual memotong kepala manusia menggunakan mandau untuk menunjukkan kekuatan, dan hanya dilakukan oleh para pemimpin, lalu yang kepalanya terpotong, digantung dan diperlihatkan ke warga. Mereka yang kalah akan mengabdikan diri kepada pemenang mengayau. Megayau juga menjadi sebuah mekanisme untuk membuktikan keperkasaan seorang pria ketika hendak meminang seorang gadis. Anak laki-laki melanglang buana mencari lawan yang kuat untuk mengadu ilmu dan bertarung sampai lawannya kalah, dan pemenang memenggal kepala yang kalah. Kemudian kepala manusia itu diperlihatkan sebagai bukti keperkasaan. Namun, saat ini tradisi mengayau telah ditinggalkan oleh orang Tidung dan semenjak orang-orang Tidung memeluk agama Islam, mengayau sudah tak dilakukan lagi, karena dianggap sangat bertentangan dengan ajaran agama Islam. Orang Tidung, baik di Nunukan maupun di Pulau Sebatik pun juga sudah tak ada lagi yang menjalankan tradisi mengayau ini (lihat Coomans, 1987 : 30).

Kedua, adalah falsafah mengenai adat-istiadat setempat yang harus dihargai. Dengan prinsip, dimanae tana biyamo, dengino kuanan sinantuk, yang berarti dimana bumi dipijak di situ langit dijunjung. Makna dari prinsip ini adalah jika terjadi pembauran antara pendatang dan kelompok penduduk asli, maka kelompok pendatang harus menaati adat-istiadat suku asli, karena adat itu berlaku pada wilayah dimana suku asli berada. Orang Tidung yang menganggap diri mereka sebagai suku asli di Pulau Sebatik, menyebabkan kelompok etnis pendatang lain harus menaati aturan adat yang terdapat di Pulau Sebatik.

Ketiga Tourotus. Tourotus secara harfiah berartitak sampai hati. Artinya bahwa Orang Tidung memiliki empati yang mendalam untuk menolong dan memperhatikan sesama anggota kerabat yang membutuhkan. Bahkan tidak hanya itu, orang di luar dari kelompoknya pun yang berkesusahan akan diberi bantuan jika memerlukannya. Tourotus inilah yang melatarbelakangi sikap saling tolongmenolong pada masyarakat Tidung, dan merupakan nilai untuk meredam konflik. Bagi orang Tidung akan berpikir panjang jika ingin memulai pertikaian, karena mereka tak sampai hati melakukan hal itu. Tapi, jika hal tersebut tidak dapat dielakkan, dan dapat menyebabkan kesabaran orang Tidung habis, maka perlawanan bisa saja terjadi.

Keempat hidup sederhana. Orang Tidung memiliki pola hidup yang sangat sederhana. Orang Tidung memiliki kebiasaan hidup secara sederhana dan subsisten. Orang Tidung hanya memanfaatkan 
segala hal yang tersedia, sebatas untuk memenuhi kebutuhan hidup. Tempat tinggal orang Tidung relatif sederhana kalau dalam Bahasa Tidung mereka menyebutnya "asol sino jadinyo gino", asal ada jadilah baiknya. Selain itu ungkapan "Suang Bagas bagambus", kalau ada beras, kita bernyanyi. Artinya kalau ada makanan yang hendak dimakan itu sudah cukup. Kemudian untuk rumah orang Tidung, mereka berprinsip yang jelas kalau hujan tidak kehujanan, dan kalau panas tidak kepanasan.

Kelima Belimpun. Nilai belimpun ini bermakna bahwa orang Tidung dalam sesama masyarakat Tidung lebih senang untuk berkumpul. Untuk itulah pola permukiman orang Tidung berpusat dan berkumpul pada sebuah tempat, tidak berpencar-pencar. Selain itu dalam nilai belimpun ini, dalam satu rumah biasanya tidak hanya dihuni oleh satu keluarga inti, tapi bisa satu keluarga luas yang terdiri dari nenek, orang tua dan anak. Namun, biasanya jika anak telah mampu untuk mendirikan rumah maka anak akan tinggal sendiri bersama keluarganya, tetapi lokasi permukimannya tidak jauh dari pusat permukiman. Orang Tidung pun, dalam kegiatan sehari-hari sering berkumpul bersama dan bercengkrama di sela-sela pekerjaan yang telah ditekuni. Nilai belimpun ini pula dapat memperkuat solidaritas sosial pada masyarakat Tidung.

Keenam, Berinut. Nilai ini yang menyebabkan orang Tidung kurang memiliki etos kerja yang tinggi, dan kurang termotivasi dalam melakukan sesuatu. Dalam melakukan pekerjaan, orang Tidung tidak terlalu berambisi, sehingga pekerjaan itu dilakukan secara pelan-pelan atau ala kadarnya saja. Ketujuh Kutika. Kutika adalah pedoman keberuntungan bagi orang Tidung untuk memulai aktifitas yang terkait dengan sistem mata pencaharian. Kutika ini biasanya digunakan orang Tidung jika ingin pergi berburu di hutan, mencari gaharu, kayu ulin, sarang burung walet. Serta digunakan sebagai pedoman untuk menangkap ikan di laut dengan cara memancing. Jadi, kutika merupakan pedoman keberuntungan untuk memulai pekerjaan. Kutika yang dimaksud orang Tidung adalah menggambarkan sosok seperti orang berdiri yang mempunyai anggota tubuh yang terdiri dari kepala, tangan, badan, dan kaki. Dan masingmasing bagian anggota tubuh memiliki makna yang dijadikan pedoman untuk memulai aktivitas. Jadi Kutika digunakan untuk menerawang waktuwaktu yang dianggap baik sehingga membawa keberuntungan.
Kedelapan. Kepunan. Nilai inibertujuan untuk menghargai tuan rumah pada saat bertamu. Orang Tidung sering menyebutnya sebagai "Ngambit ko dulu, Kepunanko nanti". Keramahtamahan orang Tidung telihat pada saat kita berkunjung ke rumah mereka. Menyodorkan makanan untuk dicicipi tamu, merupakan kebiasaan orang Tidung. Sebagai tamu kita diwajibkan untuk mencicipi makanan tersebut. Hal ini disebabkan, dalam tradisi orang Tidung jika bertamu dan tak mencicipi hidangan yang ditawarkan akan mendatangkan nasib sial. Untuk itulah dengan ungkapan Ngambit ko dulu, kepunan ko nanti. Merupakan nasehat yang ditujukan ke tamu agar tidak mendapatkan nasib buruk. Ajaran yang ingin disampaikan dibalik ini adalah dengan cara seperti ini akan saling menghormati dan menghargai antar orang Tidung.

\section{Kehidupan Keagamaan}

Dalam perspektif teori evolusi religi, sistem kepercayaan terjadi atas dasar adanya kesadaran manusia yang mendalam tentang makhluk-makhluk supranatural yang menguasai jagat raya, termasuk hidup manusia itu sendiri. Sistem kepercayaan merefleksikan kesadaran, bahwa manusia sebagai makhluk hidup, memiliki keterbatasan dalam menyikapi dan memahami dimensi makrokosmos. Di sini manusia menunjukkan ketidakberdayaan dalam menghadapi makhluk-makhluk supranatural yang lebih digdaya. Makhluk-makhluk yang digdaya ini dapat melakukan apa saja yang manusia tidak dapat lakukan (Sani, $2014: 1$ ).

Makhluk-makhluk tersebut dapat menciptakan krisis-krisis dalam kehidupan manusia, dapat menciptakan kejadian-kejadian yang luar biasa dalam hidup manusia dan dalam alam sekelilingnya. Karena itu menurut Koentjaraningrat (1964 : 41), pada umumnya bentuk religi dari sebanyak mungkin suku bangsa di dunia, akan tampak adanya empat unsur pokok yaitu; (1) emosi keagamaan atau getaran jiwa yang menyebabkan manusia menjalankan kelakuan keagamaan. (2) sistem kepercayaan atau bayang-bayangan manusia tentang bentuk dunia, alam, alam gaib, hidup, maut dan sebagainya. (3) Sistem upacara keagamaan yang bertujuan mencari hubungan dengan dunia gaib berdasarkan atas sistem kepercayaan tersebut dalam sub-sub, dan kelompok keagamaan atau kesatuan-kesatuan sosial yang mengonsepsikan dan mengaktifkan religi beserta sistem upacara-upacara keagamaannya.

Sesungguhnya, inti dalam suatu religi adalah sistem upacara keagamaan yang bertujuan 
mencari hubungan dengan dunia gaib berdasarkan atas sistem religi tersebut. Baik teori-teori yang berorientasi kepada keyakinan religi, maupun teori yang berorientasi kepada upacara keagamaan, senantiasa terdapat aktivitas dalam bentuk upacara (Koentjaraningrat, 1980 : 57) yang biasa dilakukan melalui aktivitas bersaji, berkorban dan berdoa, yang kemudian diikuti oleh serangkaian tingkah laku seperti makan bersama, menari berprosesi, bersamadi sampai pada perbuatan yang lebih ekstrim dalam bentuk intoxikasi atau perbuatan untuk menimbulkan atau menghilangkan kesadaran diri pelaku upacara.

Keesing (1992 : 28), mengaitkan model upacara peralihan misalnya sebagai sarana yang digunakan untuk menginterpretasikan upacara berkorban. Logikanya, manusia menganggap ada alam lain yang memiliki kekuasaan sebagai pengawas.

Dahulu, nenek moyang orang Tidung dari etnik Dayak, masih menganut kepercayaan para leluhur yang disebut kaharingan, yang menurut Kertodipaero (1963:16), suatu sistem kepercayaan yang meyakini gejala-gejala dinamistis serta gejalagejala monotheisme. Gejala yang dinamistis tampak dalam kebiasaan menyimpan jimat-jimat. Bendabenda yang mengandung kekuatan gaib, akan menambah kekuatan terhadap diri seseorang.

Gejala-gejala yang demomistis, yakni kepercayaan terhadap makhluk-makhluk halus atau roh-roh begitu kuat pada penganut kaharingan. Karena itu untuk menangkal kemurkaan para makhluk gaib tersebut, perlu sesajian. Namun demikian para penganut kaharingan meyakini adanya satu dewa tertinggi, yang dianggap paling berkuasa. Dia yang menciptakan langit, menciptakan bumi dan lainnya.

Seiring dengan penerimaan agama Islam pada masyarakat Tidung, kepercayaan kaharingan berangsur hilang, walaupun tidak hilang sama sekali. Ada beberapa kebiasaan yang biasa dilakukan para leluhur, masih dipertahankan, walaupun makna yang terkandung dalam kebiasaan tersebut telah berubah. Gejala seperti ini menurut Smith (dalam Koentjaraningrat, $1980: 67$ ) banyak terjadi pada banyak agama yang upacaranya tetap, tetapi latar belakang, keyakinan, maksud atau doktrinnya berubah.

Saat ini, pada umumnya orang-orang Tidung yang ada di Pulau Sebatik telah beragama Islam. Dengan demikian, sistem religi orang Tidung berlandaskan pada ajaran agama Islam. Namun demikian, masih ada ajaran adat yang mereka pertahankan yang tidak bertentangan dengan ajaran Islam. Namun untuk tradisi yang bertentangan dengan anjuran agama telah ditinggalkan oleh orang Tidung. Orang Tidung menyebutnya "yakin ko do tuhan kamat anu tenuju melainkan Allah". Sebagai ungkapan untuk menjalankan ajaran Islam dan sistem keyakinan mereka kepada Allah SWT (Muthohor, 2015 : 14).

Satu hal yang menarik, bahwa keislaman orang Tidung di Pulau Sebatik dapat digolongkan menjadi dua golongan, yakni yang mereka sebut sebagai kaum tua-tua dengan kaum muda-muda. Kaum tua-tua adalah kelompok yang terdiri dari sekumpulan para tetua adat dan pengikutnya yang bersikukuh masih mempertahankan adat tradisi dalam kehidupan sehari-hari meskipun telah mengenal ajaran agama Islam. Seperti tradisi membuka lahan, tradisi melahirkan, perkawinan, dan kematian yang dalam ritualnya memadukan antara adat dan ajaran agama.

Bahkan dari kelompok ini meyakini bahwa keislaman mereka sangatlah inklusif, karena diyakini bahwa yang mengislamkan mereka adalah wali yang dikirim oleh Allah SWT yang berasal dari langit untuk orang Tidung karena waliullah itu bersifat gaib, sehingga menjadi lebih sakral, dan terpelihara secara historis pada orang Tidung. Karena yang memperkenalkan Islam ke mereka diyakini bukan berasal dari penyiar Islam dari jalur perdagangan yang mengIslamkan orang Tidung seperti pada banyak kasus di Indonesia mengenai pola penyebaran ajaran Islam yang banyak dilakukan oleh para saudagar (pedagang Arab). Walaupun terdapat anggapan dari orang luar bahwa ajaran Islam yang dijalankan oleh orang Tidung mengandung ajaran "syirik", namun bagi orang Tidung sendiri, hal itu adalah hal yang menjadi petunjuk kebenaran dalam menjalani hidup mereka (Idris, 2017 : 142).

Kedua adalah kaum muda-muda, pada kelompok kedua ini dipelopori oleh kaum muda yang telah menempuh pendidikan di pesantrenpesantren. Dalam praktik keagamaan, kaum mudamuda ini cenderung tidak mempraktikkan lagi ajaran hasil sinkretis dari ajaran agama Islam dan adat. Mereka kaum muda ini, menjalankan praktik keagamaan yang sesuai dengan $\mathrm{Al}-\mathrm{Quran}$ dan $\mathrm{Al}$ Hadist. Masalahnya, dalam praktik keagamaan seperti shalat Jumat, kaum muda tidak diberi kesempatan oleh kaum tua untuk berceramah maupun terlibat dalam ritual keagamaan lainnya. Jadi, sistem kepercayaan yang dianut oleh orang Tidung adalah telah berlandaskan pada ajaran 
agama Islam, namun dalam bentuk praktik terjadi perpaduan antara budaya lokal dengan Islam.

Bahkan sistem religi yang dianut oleh orang Tidung menggambarkan adanya keterkaitan dengan pranata lainnya. Keterkaitan antara pranata religi dengan pranata lainnya menggambarkan bahwa sistem religi dijadikan sebagai pedoman dalam bertingkah laku pada segala aspek kehidupan, walaupun orang Tidung mengakui bahwa satusatunya agama yang mereka anut adalah agama Islam.

\section{PENUTUP}

Ketidakberdayaan orang Tidung bersaing untuk memperoleh akses di ranah ekonomi, termasuk akses terhadap sumberdaya alam, bukan semata-mata karena faktor eksternal dari kalangan para migran yang cenderung menguasai pasar dan pengelolaan sumberdaya alam, tetapi juga karena faktor internal, sebagai akibat orientasi nilai budaya orang Tidung yang begitu menghargai masa lalu.

Sistem nilai budaya yang begitu kuat menghargai masa lalu, menyebabkan adat istiadat tetap dipertahankan. Masalahnya, mempertahankan hal-hal yang baik adat istiadat, sesungguhnya sahsah saja. Namun demikian, tantangan terhadap kehidupan hari ini dan masa datang begitu kompleks, sudah barang tentu ini perlu penyesuaian dan perubahan agar orang Tidung dapat tetap eksis dan berkembang serta bersaing.

Kesadaran menyongsong masa depan dengan serangkaian perubahan sistem nilai budaya yang mendukung pembangunan terutama pembangunan masyarakat, sangat diperlukan sebagai upaya meningkatkan kesejahteraan mereka. Orang Tidung tidak perlu merasa termarginalkan dan merasa rendah diri akibat ketertinggalan dari para migran. Upaya untuk merekonstruksi identitas dengan membentuk Forum Komunikasi Orang Tidung menjadi momentum untuk membangkitkan spirit orang Tidung yang pernah jaya pada masa lalu untuk melakukan perubahan, terutama di bidang sosial, ekonomi dan pendidikan dan dengan demikian mereka dapat lebih partisipatif dalam penguatan politik identitas yang membangun.

\section{UCAPAN TERIMA KASIH}

Syukur Alhamdulillah atas berkat Rahmat Allah Swt. penulis ucapkan atas selesainya tulisan ini. Ucapan terima kasih penulis haturkan kepada semua pihakyang telah membantu dan berkontribusi mulai dari perencanaan dan pelaksanaan penelitian sampai kepada selesainya tulisan ini. Dan tak lupa, ucapan terima kasih kepada Redaksi/Pengelola Jurnal Alqalam Balai Litbang Agama Makassar yang bersedia menerima dan memuat tulisan ini.

\section{DAFTAR PUSTAKA}

Barth, Fredrick. 1988. Kelompok Etnik dan Batasannya. UI Press. Jakarta.

Batubara, H. 2014. Pulau Sebatik Ikon Kota Perbatasan : Beranda Depan Kedaulatan Bangsa. wilayahperbatasan.com. Bandung

Coomans, Mikhail. 1987. Manusia Daya, Dahulu, Sekarang, Masa Depan. Gramedia. Jakarta.

Hamzah, Amir. 1998. Sekilas Mengenai Suku Bangsa Tidung. Manuskrip Tidak diterbitkan.

Idris, Usman. 2017. Ulun Pagun: Konstruksi Identitas Orang Tidung di Pulau Sebatik. Tesis. Prog. Magister Pascasarjana Unhas. Makassar.

Keesing M. Roger. 1996. Antropologi Budaya, Suatu Perspektif Kontemporer, Ed. Kedua. Erlangga. Jakarta.

Kertodopoero, Sarwoto. 1963. Kaharingan Religi dan Penghidupan di Petuluan Kalimantan. Sumur. Bandung.

Koentjaraningrat. 1964. Tokoh-Tokoh Antropologi. PT. Penerbitan Universitas. Jakarta.

Koentjaraningrat. 1980. Beberapa Pokok Antropologi Sosial. Dian Rakyat. Jakarta.

Muthohar, Ahmad. 2015. Islam Dayak: Dialektika Identitas Dayak Tidung di Pulau Sebatik. Fatwa Pub. Semarang.

Okhosima, M. 2003. Ethnic Background of The Tidung : Investigation of The Extinct Rules of Coastal North East Borneo. Didownload dari http://www.kuis.rcjppiec/member/ okushima/ronko/tidung.pdf. tanggal 10 Desember 2015.

Puersen, C.A. 1976. Strategi Kebudayaan. Penerbitan Yayasan Kanisius. Yogyakarta.

Sani, M. Yamin. 2014. Erau: Politik Kebudayaan dan Modernisasi di Kabupaten Kutai Kartanegara Kalimantan Timur. Makalah. Makassar.

Sani, M. Yamin, dkk. 2017. Orang Tidung di Tapal Batas : Membangun Negeri Merawat Harmoni. Laporan Penelitian Professorship Universitas Hasanuddin. Makassar.

Universitas Indonesia. 1980. Sejarah Teori Antropologi I. UI Press. Jakarta. 